KAPL-P-000184

(K97078)

CONF-970701--

\title{
THERMOPHOTOVOLTAIC EMITTER MATERIAL SELECTION AND DESIGN
}

G. Nichols, P. C. Saxton, et. al.

July 1997

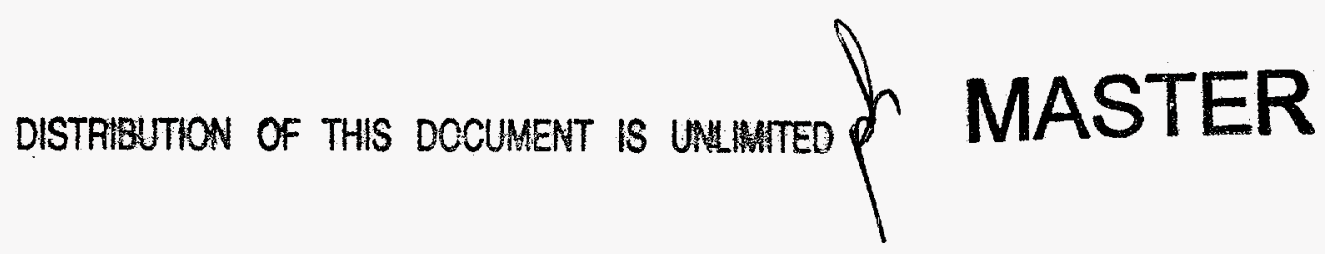

\section{NOTICE}

This report was prepared as an account of work sponsored by the United States Government. Neither the United States, nor the United States Department of Energy, nor any of their employees, nor any of their contractors, subcontractors, or their employees, makes any warranty, express or implied, or assumes any legal liability or responsibility for the accuracy, completeness or usefulness of any information, apparatus, product or process disclosed, or represents that its use would not infringe privately owned rights. 


\section{DISCLAIMER}

This report was prepared as an account of work sponsored by an agency of the United States Goverament. Neitber the United States Government nor any agency thereof, nor any of their employees, makes any warranty, express or implied, or assumes any legal liability or responsibility for the accuracy, completeness, or usefulness of any information, apparatus, produch, or process diselosed, or represents that its use would not infringe privately owned rights. Refereace berein to any specific commercial product, process, or service by trade name, trademarte, inanufacturer, or otherwise does aot necessarily constitute or imply its endorsement, recommendation, or favoring by the United States Government or any agency thereof. The views and opinions of authors expressed herein do not necesearify state or reflect those of the United States Governmens or any agency thereof. 


\section{DISCLAIMER}

Portions of this document may be illegible in electronic image products. Images are produced from the best available original document. 


\title{
THERMOPHOTOVOLTAIC EMITTER MATERIAL SELECTION AND DESIGN
}

\author{
Patrick C. Saxton \\ Angela L. Moran \\ Mark J. Harper \\ Keith W. Lindler \\ United States Naval Academy \\ 590 Holloway Rd. \\ Annapolis, MD, 21402 \\ Phone (410) 293-6534 Fax (410) 293-2591
}

\begin{abstract}
Thermophotovoltaics (TPV) is a potentially attractive dircet energy conversion technology. It reduces the need for complex machinery with moving parts and maintenance. TPV generators can be nun from a variety of heat sources including waste heat for sinaller scale operations.

The Unired States Naval Academy's goal was to build a small experimental thermophotovoltaic generator powered by combustion gases from a General Electric T.58 helicopter gas turbine. The design of the generator imposes material limitations that directly affect emirer and stuctural materials selection. This paper details emitter material goals and requirements, and the methods used to select suitable candidate emitter materials for further testing.
\end{abstract}

\section{OBJECTIVES}

The objective was to select an eminter material based on an initial design that would withstand the cnvironment, temperatures in excess $1300^{\circ} \mathrm{C}$, and achieve an emissivity of at lesst 0.90. Additional material concems included thermal shock resistance, themal conductivity, and machinability.

\section{METHODOLOGY}

The objectives of this project were achieved through the following primary steps:

Background Research - A thorough seview of previous thermophorovoltaic research and processes involved in TPV energy generation was conducted. Supporting research also included an involved study of materials and their associated marerial properties.

Experimentation - Candidare materials were tested for oxidation resistance, thermal shock resistance, and emissivity in cases where the information was not available in technical literanure.
Material Selection - Final emitter material selection was based on TPV system requirements, data obtained through background research, and data from experimentation.

\section{THE FUNDAMENTAL PROCESS}

A TPV generator is composed of three main parts: a thermal radiator, a thermal radiation filter, and a scmiconductor diode. In many instances, the thermal radiation fitter is incorporated into the semiconductor diode, called a TPV cell (Borowsky and Dziendziel, 1994). In this project the TPV cells and filters (one unit) were supplied to the Naval Academy, hence two components of the gentrator are constant, leaving the crnitter material as the final variablc.

The choice of material to serve as the emitter dictates the characteristics of the emitted radiation. Planck's Law reveals how an ideal material radiates energy as a function of its temperanre, but no material is ideal. Emissivity is the property used to quantify how closely a material models an ideal blackbody radiator. It is the material's emissivity that determines how the emitter will radiate its energy at a given temperature (DeWith and Incropera, 1996). Additionally, emissivity directly infuences the ovcrall system efficiency.

\section{INITIAL SYSTEM DESIGN}

The design of the system determines the properties that are required of the material components that constitute the design. In a high ternperature design project such as this, determining which portions of the design will experience clevated or cyclic temperatures is critical. Additionally, determining which materials will be exposed to combustion gases or heavy loading is imponant for determining the design life of the materials. The following is a brief overview of the United States Naval Academy's initial system design and the resulting material concems. 


\section{INITIAL DESIGN}

The TPV generator is to be powered by combustion gases from a General Electrict-58 helicopler gas turbine. Figure 1 is a diagram of the initial TPV system design:

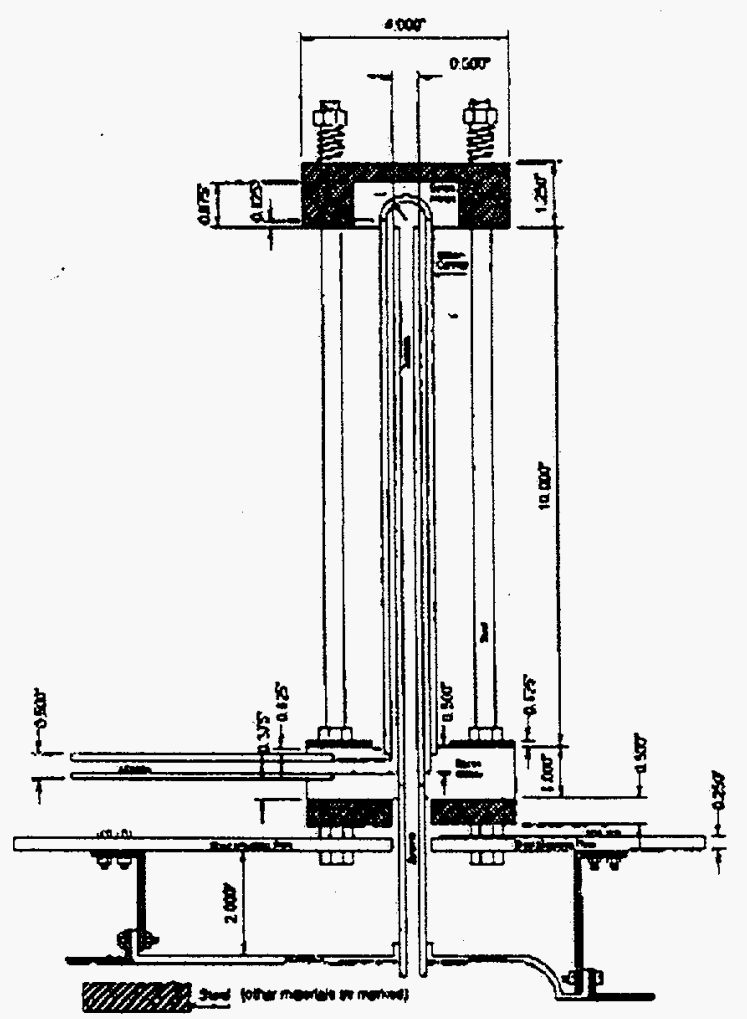

FIGURE 1. SCHEMATIC DIAGRAM OF THE ASSEMBLY

It can be seen that the combustion gases are extracted from the combustion chamber of the T-58 by way of an extraction tube. This tube extends from the inside of the combustion chamber to the inside of the emitter. The pressure inside of the combustion chamber is approximatcly $120 \mathrm{psi}$, which is sufficient to force combustion gases up through the narrow opening of the extraction lube. The combustion gases pass through the tube and exit at the top. At this point, the gases are re-directed back down along the outside of the drawing rube within the confines of the cylindrical emitter. The gases then exit through an exhaust port at the base of the emitier, located in the base plate. The TPV cells (not shown) are located in close proximity to the outside surface of the emitter to absorb the emitted radiation. Water cooled channels are placed against the backside of the TPV cells to serve as heat sinks, because the cells are more efficient when cooled below $90^{\circ} \mathrm{C}$.

\section{EXHAUST GASES}

The composition of the gases" affects the corrosion mechanisms that may result from high temperatures. At increasingly high temperatures, corrosion rates accelerate, which makes accurate ideatification of potential corrosion hazards vita!.

The exhaust gases from the gas turbine can be expected to contain the following (MSDS JP-S):

\author{
- Carbon monoxide \\ - Carbon dioxide \\ -Water \\ -Hydrocarbons \\ -Nitrous oxide
}

\section{EMITTER MATERIAL PROPERTIES}

The performance of the cmitter is most directly linked to the material from which it is constructed. Thus the properties of that material influence the ovcrall performance of the gencrator. Matching the emitter requircments to the propertics of the material chosen is therefore critical. It is unlikely that one specific material will meet every single requirement for the emitter. It is more likely that the best material will require compromise; for example, one material may have a high melting temperature and emissivity but require a coating to provide for corrosion resistance. In any case, the important ideal emitter properties must first be identified and their significance weighted, before compromises can be made.

\section{Melting Temperature}

The material chosen must be able to withstand $1300^{\circ} \mathrm{C}$ without degrading. It is conceivable that the inside of the emitter may reach temperatures in excess of $1300^{\circ} \mathrm{C}$ during testing, so it is also imporant that there be some tolerance for even higher iemperaiures. Essentially, the higher the melting temperature the better. Some materials sublime rather than melt. This must also be avoided.

\section{Emissivity}

The objective of this research is to find a suitable emitter material that has an emissivity greater than 0.90 . Unfortunately emissivity is not a property that is commonly known for most materials, especially for newly developed materials. It is importane, therefore, to understand the fundamentals of emissivity in order to speculate as to which materials are worth investigating, since emissivity testing is both difficult and expensive.

The cmission from a material is a direct result of the energy released by the oscillations or transitions of the electrons in that material. The oscillations of the electrons are dependent on the internal energy of the material, which in tum is dependent on its temperature. Radiation emcrging from a finite volume of matter is the integrated effict of the local emission throughout the volume. In most solids though, radiation emitted from interior molecules is rapidly absorbed by adjoining molecules. Therefore, radiation that actually escapes the surface of the body originates from the molecules that ape within approximatcly 1 um from the exposed surfacc. Due to this effect, radiative emission is viewed as a surface phenomenon for solids.

Often, when high emissivities are required, materials must have their emissivities enhanced. Since the emissivity of a matcrial is a function of the character of its surface, techniques for enhancing a material's emissivity focus on altering its surface. There are two main approsches to altering the surface of an cmitting material: coating the surface and texturing the surface.

If a material has a low emissivity, its emissivity may be eahanced by applying a thin layer of another material that has a higher emissivity. The difficulty in this technique lies in matching the proper coating with the material. Just as in alloying 
metals and joining materials, some materials respond favorably to coarings while others do not.

The other technique for improving a material's emissivity is surface rexuring. NASA Lewis Research Center in Cleveland, Ohio has developed three techniques for enhancing surface cmissivity that were being considered for this project. All of these techniques involve ion spurtering. The three principlc techniques are sputter etching. sputter deposition, and sputter texturing. Sputter etching is the process of removing material from a surface by bombarding it with a stream of high cncrgy ions or ncutral particles. Surface atoms and molecules are ejected from the surface of the target material due to interactions with the bombarding particles. The end result is a highly pitted surface, which enhances emissivity. Sputter deposition is the process by which material that is sputter etched from a target is accumulated on the surface of another material. Essentially, sputter deposition is similar to sputter etching except that the goal is to use the ejected atoms and molecules from the sputter etching process rather than to actually etch the material. The fundamental idea behind sputter texturing is that the surface material have distinct spatial variations in its sputter yicld, meaning that different regions of the target material will eject more atoms when exposed to the ion beam. Ulimately, this creates the texture as areas of the surface will in time have ejected significantly more atoms than neighboring regions. Ideally, the emitter material will be a material that does not require surface texturing or coating (Banks, B. A., 1981)

\section{Corrosion Resistance}

At $1300^{\circ} \mathrm{C}$, most matcrials degrade quickly and easily. Few materials, in fact, can withstand these temperatures by themselves and nor corrode in some manner. An additional concern in this application is the possibility of corrosion products depositing on the TPV cells.

If absolute corrosion resistance cannot be provided, then it may be necessary to compare each potential material's corrosion rate. In this scenario, the goal would be to choose the emitter material that will last the longest. This would at least enable the overall desigo to be tested until an inproved emitter is discovered.

\section{Thermal Expansion}

The jdeal emitter would have a low coefficient of thermal expansion. Thermal expansion will not directly affeet the performance of the emitter, but it will influence the design of the overall TPV generator. At $1300^{\circ} \mathrm{C}$, thermal expansion can be considerable. If steps are not taken to allow for this expansion, considerable stresses could develop in the eminter material, potentially causing catastrophic failure. In the inirial design, springs are located at the top of the generator to account for the thermal expansion of the emitter. Ideally, if thermal expansion cannot be minimized, thermal expansion coefficients of neighboring materials should match, allowing for the entirc structure to expand in unison. This is particularly critical in rcgions whese materials are tightly fitted together, such as the end caps that are used to seal the emitter tube.

\section{Thermal Shock}

When the T-58 gas turbine is ignited, combustion gases immediately impinge on the extraction tube and emitter assembly.

This sudden surge from room temperature to $1600^{\circ} \mathrm{C}$ in a gaseous environment can cause catastrophic failure in many materials due to rapid thermal expansion which can induce extreme stress. A material's crystal structure alters at high temperatures, thus if the temperature change is sudden, a rapid structural change can induce material failure. Typically, materials with low coefficients of thermal expansion are more resistant to thermal shock (Richerson, 1992).

\section{Thermal Conductivity}

The thermal conductivity of the emitter directly affects the efficiency of the TPV generator. It is very difficult to heat the emitter up to $1300^{\circ} \mathrm{C}$ with the combustion gases of the $I-58$ generator due to the low convection coefficient of most gases. If the emitter is a poor thermal conductor, it is difficult for the ourside of the eminer to reach $1300^{\circ} \mathrm{C}$, due to the large temperature difference between the inside and outside of the emitter. The emissive power of the emitter is a direcr function of the emitter's outside surface temperature, therefore the overall generator's efficiency can be drastically reduced if a lage temperature gradient exists between the inside and outside walls of the emitter.

\section{Machinability}

Although machinability is difficult to quantify, the perfeet theoretical design is worthless if it cannor be buile. Marny of the enitter candidate marerials are ceramics and ceramic composites, and therefore are difficult to machine. This inhereatly limits the geometry of the emitter. Since most materials can be manufactured cylindrically, a cylindrieal emirter seems most practical. Depending on the material however, shaping and sizing the cylindrical cmitter may prove difficult.

\section{INITIAL MATERIAL SELECTION}

Initial material selection represents the first attempt at limitiag the number of samples to be tested for the critical eminer properies. The approach that was used was to first list a large number of materiais and gather published data on those materials. From that listing, the candidaze materials to be further tested were chosen. Once the candidate materials were determined, they were ordered from manufacturers and suppliers.

The list of initial materials represents an attempt to sample materials from a broad range of possible high temperature candidates: monolithic ceramics, composite ceramics, and refractory metals. The initial materials included:

Boron Nitride

$\mathrm{Nb}$ based $\mathrm{C}-103$

Ni based MA758

Fe based MA956

\section{EXPERIMENTATION}

Onee the candidate emitter materials were selected, initial testing was needed to narrow the candidates. Further testing was conducted on those materials deemed worthy. This was necessary because some of the testing could not be done at the U.S. Naval Acadeny and had to be contracted out to othet laboratories. Costs were controlled by limiting the number of samples that were tested outside of the Academy. 
Initial tests were either pass or fail. In the process of testing for potential emitter materials, considesation was given to whether a material might also function as a structural material. Materials that were completely ruled out where those materials that could not be used for either the eminer or the structural components of the IPV assembly.

\section{Initial Oxidation Experiment}

The objective of the experiment was to craluate how samples of differen materials responded to $1300^{\circ} \mathrm{C}$ free air environment. The initial candidate materials were placed in a Thermolyne fumace at $1315^{\circ} \mathrm{C}$.

Several materials were eliminated from consideration based on the results of this experiment. Specifically, tungsten-rhenium and C-103 demonstrated tendencies to corrode in the fumace. Tungsten-rhenium vaporized and left a yellow rhenium rcsiduc. A heavy, brittle, white oxide formed on the C-103 sample causing significant degradation.

\section{Follow-up Oxidation Experiment}

A second round of oxidation testing was conducted also using the Thermolyne fumace. The objective of this test was to produce quantitative results that compare mass changes due to oxidation for the differcnt candidate materials. In some cases, the materials that had been eliminated in the initial testing were retested in order to generate data on them.

The quantitative rcsults follow:

$\begin{array}{lc}\text { Material } & \text { Mass Change } \\ \text { Boron Nitride } & -2.42 \% \\ \text { C-103 } & +15.54 \% \\ \text { MA956 } & +1.09 \% \\ \text { Nb-1\%Zr } & +1.77 \% \\ \text { Silicon Nitride } & +0.10 \% \\ \text { Tungsten-rhenium } & -100.00 \% \\ \text { Zirconia } & -0.04 \%\end{array}$

$\mathrm{BN}, \mathrm{C}-103, \mathrm{MA} 956, \mathrm{Nb}-1 \% \mathrm{Zr}$, and $\mathrm{WRe}$ all demonstrated significant mass changes that eliminate them as emitter candidate materials. Silicon nitride and zirconia demonstrated a resistance to oxidation.

\section{Thermal Shock Testing}

Thermal shock testing was conducted at Technology Assessment \& Transfer, Inc. in Maryland. The objective of the test was to determine which candidate materials withstood the therrnal shock that results when the combustion gases of the T-58 gas rurbine first enter the emitter asscmbly.

The individual candidate materials were exposed to a flame from an acetylene torch and heated until they reached $1300^{\circ} \mathrm{C}$. An optical pyrometer was used to measure the temperature of the samples to determine when they had reached $1300^{\circ} \mathrm{C}$. Two samples of each material were heated with the torch. so that one could be air quenched and the other water quenched. Thermal shock on heat-up is the greatest concern for the emitter, but quenching was performed to develop an understanding of how the emitter material would perform once the $T-58$ gas uurbine was extinguished and the emister was allowed to cool

Zirconia was the only material that catastrophically failed upon heating. C-103, MA956, and $\mathrm{Nb}-1 \% 2 \mathrm{Z}$ all generated oxides that cracked from ais quenching and shattered from water quenching. Tungsten-thenium left a yellow thenium residue after being removed following heating. These materials were eliminated from consideration since they are likely to fail after repeated start-ups of the gas turbine.

\section{Emissivity Testing}

Emissivity testing was conducted at NASA Lewis Research Center in Cleveland, $\mathrm{OH}$. This testing was the most citical part of the research, since few materials exhibit emissivities greater than 0.90

In all, eleven materials were tested for their emissivity. The materials tested ranged from ceramic composites to refractory metals. At this point, many of the materials had been eliminated from consideration because of oxidation or thermal shock problems, but they were still tested to provide genernl data and to serve as a basis for comparison.

Additional materials were included for testing because initial emissivity data on silicon carbide indicated that ceramic composites typically have higher emissivities. A variety of carbon and silicon carbide composite samples were gathered from various manufacturers for screening. These materials will be tested for other properties in the neap future since emissivity testing confirmed the initial data.

The testing procedure follows. A series of lamps and filters were used to selectively radiate the samples with light of a spccific wavelength. A system of mirrors was then used to capture the light that was reflected from the samples surface. This light was then directed to an integrator that calculated the reflectivity of the material's surface. The emissivity of the sample was then extrapolated from the reflectivity. A plot of the sample's reflectivity versus wavelength was then displayed on a nearby monitor that was connected to the system. The data used to generate the plots was saved. Correction factors were applied to account for the fact that the atmosphere within the test chamber was not a vacuum and that the test was conducted at room temperature. The mererial's emittance was extrapolated and plotted as a function of the incident wavelength and corscsponding temperature, as shown in Figure 2-12.

The results of the testing were as follows:

Material

Woven $\mathrm{C} / \mathrm{SiC}$

CVD SiC

SiC/Si

SiC/Si (oxidized)

CVD SiC/C

$\mathrm{ZrB}_{2} / \mathrm{SiC}$

CVD HAC

HfC w/ $10 \% \mathrm{TaC}$

BN

$\mathrm{Nb}-1 \% \mathrm{Zr}$

WRe

SiN

\section{Emissivity at $1500 \mathrm{~K}$}

0.86

0.90

0.88

0.93

0.88

0.78

0.67

0.70

0.26

0.33

0.22

0.87 
Emittance as a Funclion of Temperature for Selected Materials

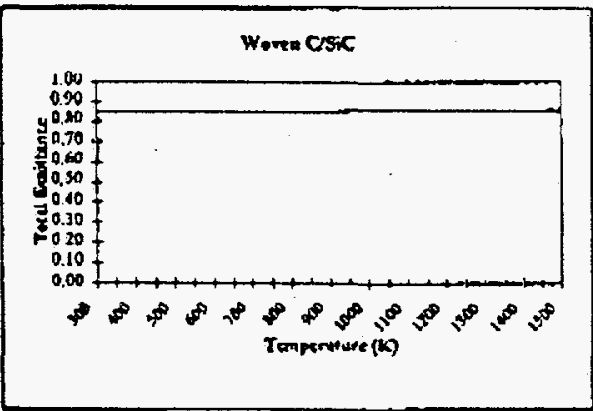

FIGURE 2. EMITTANCE OF WOOVEN CISIC

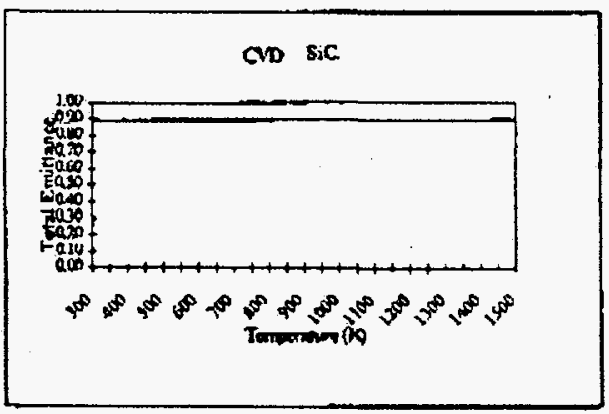

FIGURE 3. EMITTANCE OF CVD SIC

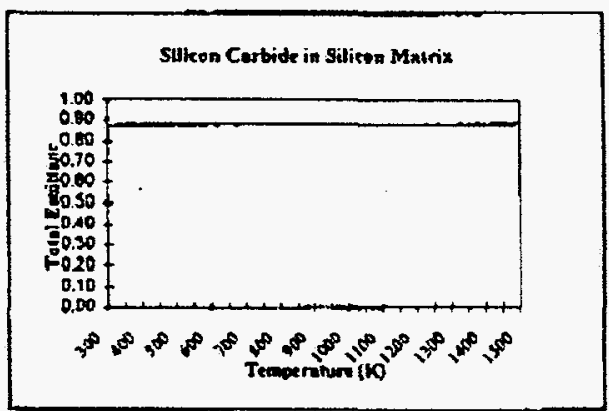

FIGURE 4. EMITTANCE OF SiC/Si

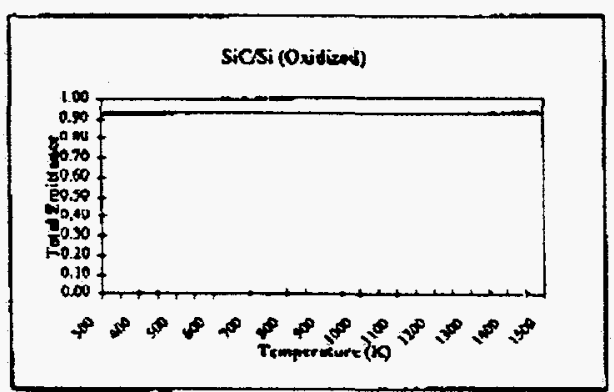

FIGURE 5. EMITTANCE OF OXIDIZED SiC/Si

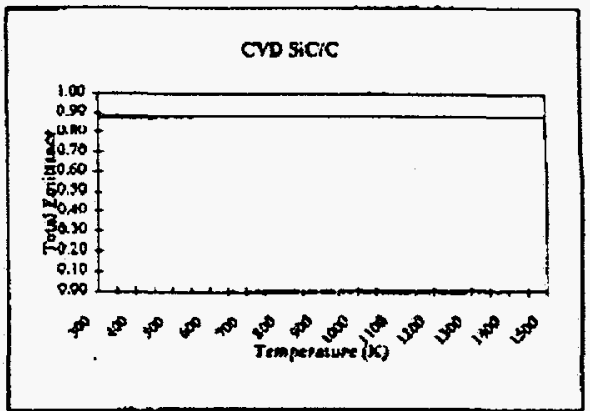

FIGURE 6. EMITTANCE OF CVD SiCIC

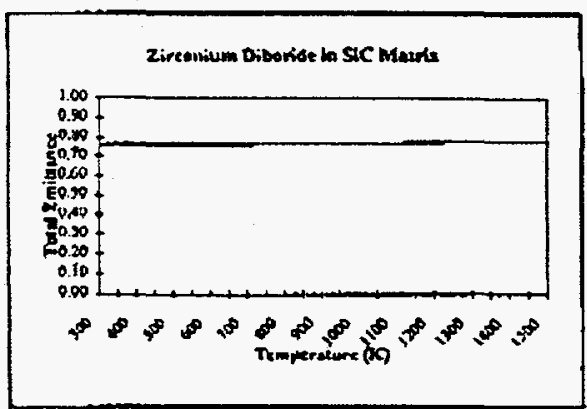

FIGURE 7. EMITTANCE OF $Z_{1 B_{2}} \mathbb{N}$ SiC

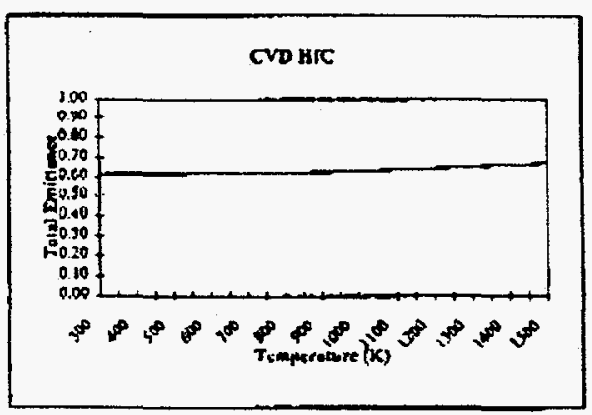

FIGURE 8. EMITTANCE OF CVD HEC

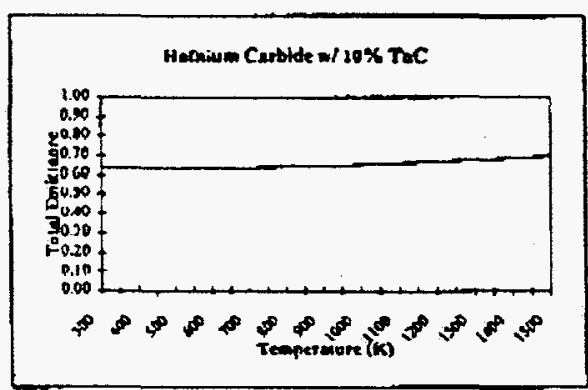

FIOURE 9. EMITTANCE OF HFC w $10 \% \mathrm{TaC}$ 


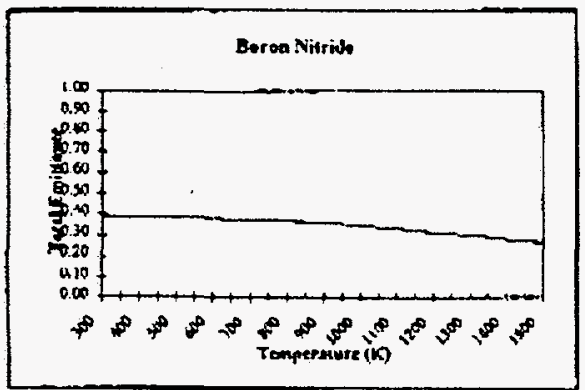

FIGURE 10. EMITTANCE OF BORON NITRIDE

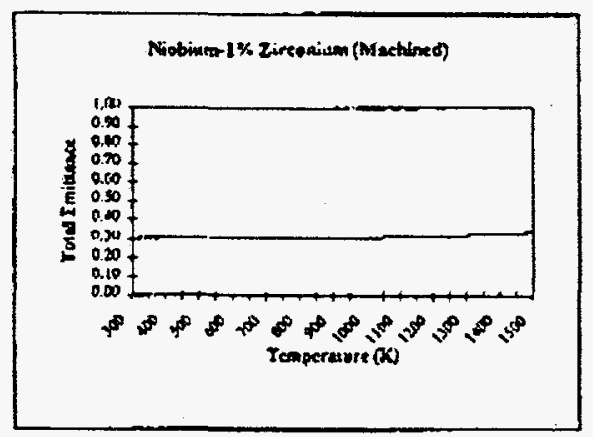

FIGURE 11 . EMITIANCE OF $\mathrm{Nb}-1 \% \mathrm{Zt}$

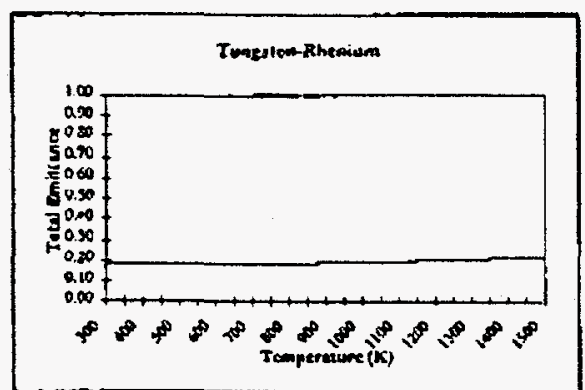

FIGURE 12. EMITTANCE OF WRe

An oxidized sample of $\mathrm{SiC} / \mathrm{Si}$ had the highest emissivity, and in fact had an emissivity 0.05 greater than non-oxidized $\mathrm{SiC} / \mathrm{Si}$. This indieates that the performance of this material improves as it oxidizes during TPV generator opcration. A one inch diameter tube of SiC/Si has been ordered for additional testing.

CVD SiC had the second highest emissivity at 0.90 . CVD SiC is a typical oxidation resistant coating applied to carbon composites. This high emissivity indicates that ceramic composites with a SiC overcoat are a promising oplion.

A silicon-carbide fibcr composite has been ordered for additional testing. This composite will undergo a reverse thermal gradient chemical vapor infiltration process by which carbon will be infiltrated into the fiber weave. A silicon carbide overcoat will then be applied to the surface of the infiltrated fiber wcaye.

\section{CONCLUSIONS}

Oxidation, thermal shock, and emissivity testing demonstrated thar monolithic ceramics and refractory metals cannot withstand the environment of this TPV generator. Ceramic composites were the only materials that possessed emissivities equaling or exceeding the goal of 0.90 .

Two materials were found that met the requirements of the thermophorovoltaic generator: lightly oxidized $\mathrm{SiC} / \mathrm{Si}$ and the CVD SiC overcoat that is typically applied to composite ceramics to provide oxidation protection. Larger samples of these materials have been ordered in one inch diameter tubes to closely model the actual emitter.

\section{REFERENCES}

Banks, B. A., "Ion Beam Applications Research - a 1981 Surnmary of Lewis Research center Programs," NASA TM81721, 1981.

Borowsky, E. W. and Dziendzjel, R. J. '(eds.), "Thermophotovoltaics Primer," 1994.

DeWin, D. P. and Incropera, F. P., Introduction to Heat Transfer, New York: John Wiley \& Sons, 1996.

Richerson, D. W., Modern Ceramic Engineering. New York: Marcel Dekker, Inc., 1992. 